\title{
EXPERIMENTAL STUDY OF THE OLDER PRESCHOOL CHILDREN'S VOCABULARY DEVELOPMENT WHILE ACQUAINTING WITH PROFESSIONS
}

\author{
ESTUDO EXPERIMENTAL DO DESENVOLVIMENTO VOCABULÁRIO DE \\ CRIANÇAS PRÉ-ESCOLARES MAIS VELHAS AO CONHECEREM PROFISSÕES
}

\author{
ESTUDIO EXPERIMENTAL DEL DESARROLLO VOCABULARIO DE LOS NIÑOS \\ MAYORES EN PREESCOLAR MIENTRAS SE CONOCE CON PROFESIONES
}

\author{
Olena HNIZDILOVA ${ }^{1}$ \\ Yulia LUKASHOVA ${ }^{2}$ \\ Svetlana BURSOVA ${ }^{3}$ \\ Nataliia YUDINA ${ }^{4}$ \\ Olha HRYSHKO
}

\begin{abstract}
The paper mainly highlights the features of older preschool children's acquaintance with the professional activities of adults. The theoretical and methodical bases of the researched issue are generalized. The structural components of the formation of preschoolers' ideas about professions are highlighted. The results of a pilot study to determine the level of older preschool children's acquaintance with the occupations of adults are presented. The influence of the place of residence on the depth of children's knowledge about the professional activity is found out. It is revealed that older preschool children understand the meaning of words that characterize the adults' professional activities but rarely use them in their active speech. Based on the results obtained, it is stated that children in urban areas are more familiar with the professions that have emerged in recent years (beautician, blogger, baker, manager, cameraman, photographer, cashier, president and taxi driver), but ignore the agricultural and factory professions. Preschoolers in rural areas are more inclined to occupations related to technology and agriculture. The influence of gender on children's preferences for choosing a particular profession is analyzed. It is observed that girls prefer professions related to care, service (doctor, cook, hairdresser and veterinarian), for boys the most desirable professions are heroic, courageous and professional (policeman, firefighter and
\end{abstract}

\footnotetext{
1 Poltava V. G. Korolenko National Pedagogical University (PNPU), Poltava - Ukraine. Professor of the Department of Preschool Education. Doctor of Pedagogical Sciences. ORCID: https://orcid.org/0000-00017706-2427. E-mail: gnizdilovae@gmail.com

2 Poltava V. G. Korolenko National Pedagogical University (PNPU), Poltava - Ukraine. Postgraduate of the Department of Preschool Education. ORCID: https://orcid.org/0000-0001-8540-9531. E-mail: julia.lukashova95@gmail.com

${ }^{3}$ Poltava V. G. Korolenko National Pedagogical University (PNPU), Poltava - Ukraine. Senior Lecturer of the Department of Preschool Education. ORCID: https://orcid.org/0000-0002-0063-3567. E-mail: svetlanabursova83@gmail.com

${ }^{4}$ Poltava V. G. Korolenko National Pedagogical University (PNPU), Poltava - Ukraine. Associate Professor of the Department of Psychology. Ph.D. in Psychology. ORCID: https://orcid.org/0000-0002-1545-8730. E-mail: Nata.yudina17@gmail.com

${ }^{5}$ Poltava V. G. Korolenko National Pedagogical University (PNPU), Poltava - Ukraine. Associate Professor of the Department of Preschool Education. Ph.D. in Pedagogics. ORCID: https://orcid.org/0000-0002-9149-3992. E-mail: missoliva20@gmail.com
}

RPGE- Revista on line de Política e Gestão Educacional, Araraquara, v. 25, n. esp. 3, p. 1860-1873, Sep. 2021. e-ISSN: 1519-9029 DOI: https://doi.org/10.22633/rpge.v25iesp.3.15597 
driver). It is concluded that the professions well known to children in the 20th century are hardly known to modern children (astronaut and postman).

KEYWORDS: Children's acquaintance. Preschool age. Vocabulary enrichment. Education.

RESUMO: $O$ artigo destaca as características da familiaridade de crianças pré-escolares mais velhas com as atividades profissionais de adultos. As bases teóricas e metodológicas do problema pesquisado são generalizadas. Os componentes estruturais da formação das ideias dos pré-escolares sobre as profissões são destacados. Os resultados de um estudo piloto para determinar o nível de familiaridade de crianças pré-escolares mais velhas com as profissões de adultos são apresentados. Verifica-se a influência do local de residência na profundidade do conhecimento das crianças sobre a atividade profissional. Revela-se que crianças préescolares mais velhas entendem o significado das palavras que caracterizam a atividade profissional dos adultos, mas raramente as utilizam em sua fala ativa. Afirma-se que as crianças das áreas urbanas estão mais familiarizadas com as profissões que surgiram nos últimos anos (esteticista, blogueira, confeiteira, gerente, cinegrafista, fotógrafo, caixa, presidente e taxista), mas ignoram as profissões agrícolas e de chão de fábrica. Os préescolares de áreas rurais são mais inclinados a profissões relacionadas à tecnologia e à agricultura. A influência do gênero nas preferências das crianças para escolher uma determinada profissão é analisada. Observa-se que as meninas preferem profissões relacionadas ao cuidado, serviço (médico, cozinheiro, cabeleireiro e veterinário), para os meninos as profissões mais desejáveis são heroicas, corajosas e profissionais (policial, bombeiro e motorista). Conclui-se que as profissões bem conhecidas das crianças no século 20 quase não são conhecidas pelas crianças modernas (astronauta e carteiro).

PALAVRAS-CHAVE: Conhecimento das crianças. Idade pré-escolar. Enriquecimento de vocabulário. Educação.

RESUMEN: El documento destaca las características del conocimiento de los niños mayores en edad preescolar con las actividades profesionales de los adultos. Se generalizan las bases teóricas y metódicas del tema investigado. Se destacan los componentes estructurales de la formación de las ideas de los preescolares sobre las profesiones. Se presentan los resultados de un estudio piloto para determinar el nivel de conocimiento de los niños mayores en edad preescolar con las profesiones de los adultos. Se descubre la influencia del lugar de residencia en la profundidad del conocimiento de los niños sobre la actividad profesional. Se revela que los niños mayores en edad preescolar comprenden el significado de las palabras que caracterizan las actividades profesionales de los adultos, pero rara vez lo usan en su discurso activo. Se ha afirmado que los niños de zonas urbanas están más familiarizados con las profesiones que han surgido en los últimos años (esteticista, bloguera, repostera, gerente, camarógrafo, fotógrafo, cajero, presidente y taxista), pero ignora las profesiones agrícolas y laborales. Los niños en edad preescolar de las zonas rurales están más inclinados a profesiones relacionadas con la tecnología y la agricultura. Se analiza la influencia del género en las preferencias de los niños para elegir una determinada profesión. Se observa que las niñas prefieren profesiones relacionadas con el cuidado, el servicio (médico, cocinero, peluquero y veterinario), para los niños las profesiones más deseables son heroicas, valientes y trabajadoras (policía, bombero y conductor). Se concluye que las profesiones conocidas por los niños en el siglo XX, los niños modernos casi no las conocen (un astronauta y un cartero). 
PALABRAS CLAVE: Conocimiento de los niños. Edad pré-escolar. Enriquecimiento de vocabulário. Educación.

\section{Introduction}

The rapid development of technology and the strengthening of globalization trends in the world economy have led to significant changes in the organization of goods and services production (CHIHIRINA, 2011; ANTONOVA; GRISHNJAEVA, 2017; ZHAMARDIY et al., 2019). It has led to the creation of the new spheres of activity and the transformation of the existing ones. At the present stage, labor is characterized by the emergence of new professions, as well as changes in the content of functional responsibilities of people (CONEWAY et al., 2020; ZHAMARDIY et al., 2019). Given this, there is a need to form a generation of employees who could compete in a modernized labor market. This process will be more effective if it starts in early childhood (LOHINOVA, 1978; DONCHENKO et al., 2020; GRIBAN et al., 2018; ZHAMARDIY et al., 2020).

Preschool children's acquaintance with professions is an integral part of the holistic picture of the world formation, ideas about social reality, connections, and attitudes (GUILFOYLE, 2013; HNIZDILOVA; LUKASHOVA, 2020). Acquiring knowledge of the adult's professional activities stimulates the emergence of a new type of preschoolers' behavior (KONONETS et al., 2020). It is mediated by the ideas about the labor and social functions of people and the importance of labor (KORNOSENKO et al., 2020). The ideas received at preschool age and the formed value attitude to labor will give children a chance to make right professional decisions (MAKEEVA, 1989; SHKOLA et al., 2020). Appropriately organized career guidance will help to gradually form a preschooler's willingness to independently plan, analyze and implement their path of career development (SHKOLA et al., 2019).

Despite the significant number of scientific papers, which investigated the issue of forming children's knowledge about the professions connected with the working and agricultural sector, the issue of acquainting preschoolers with modern professions remains insufficiently revealed, as it is an important factor in the child's self-affirmation in the future (YERSHOVA, 2013; ZHAMARDIY et al., 2020). 


\section{Materials and Methods}

The aim of the study is to highlight the results of the diagnosis of preschool children's level of acquaintance with professions and the specifics of adult professional activity, and the impact of a number of factors (gender, place of residence) on their level of acquaintance and career choice.

We used the following research methods: analysis, comparison, and generalization of data from psychological, pedagogical, and methodological literature; observation of children's play activities; conversation with older preschool children; role-playing («A kindergarten», «A hospital», «A shop»), building games («On the farm», «A shop», «A stadium») and didactic games («Who works where?», «Who needs what stuff for work?»).

We conducted a pilot study to determine preschool children's level of acquaintance with the professions of adults. Using conversations, observations, and didactic games, we measured the depth of older preschool children's knowledge about the professional activities of adults. We determined the criteria, indicators, and levels of children's acquaintance with professions. Preschool institutions of Poltava, Dnipropetrovsk, Sumy, Kharkiv, Zakarpattia regions of Ukraine were the bases of the pilot study. We interviewed children from urban and rural areas to investigate the correlation between children's acquaintance with professions and their place of residence.

The following institutions took part in the research: Poltava preschool educational institution n. 36 «School of Health», Poltava preschool educational institution (nurserykindergarten) n 74 «Dzhereltse», Poltava preschool educational institution (nurserykindergarten) of a combined type n. 6 «Cheburashka», Institution of preschool education n. 2 «Berizka» in Hadiach, Preschool educational institution (nursery-kindergarten) n. 5 «Berizka» in Karlivka, Preschool educational institution n. 1 «Teremok» in Lokhvytsia, Preschool educational institution «Vyshenka» of Kyshyniv village council of Hadiach district, Harkushyntsi preschool educational institution (kindergarten) «Prominchyk» of Myrhorod district, Polohy educational complex of Novi Sanzhary district, Hradyzk preschool institution n. 4 «Sonechko» of Hlobyno district, Preschool educational institution «Podolianochka» of Dykanka district, Rudkivka branch of the municipal institution «Kytaihorod institution of general secondary education of I-III degrees» of Kytaihorod village council of Tsarychanka district, Municipal institution of preschool education (nursery-kindergarten) of a combined type n. 10 «Diuymovochka» in Novomoskovsk, Municipal institution «Ivano-Mikhaiivka educational complex» of Novomoskovsk district, Kylchyn preschool educational institution 
«Sonechko» of Mahdalenivka district, Babaiky preschool educational institution «Barvinok» of Tsarychanka district of Dnipropetrovsk region, Municipal «Preschool Education Institution n. 2» in Irshaiev of Zakarpattia region, Preschool education institution «Barvinok» in Nedryhailiv village of Sumy region, Cherneshchyna educational complex of Zachepylivka district of Kharkiv region. A total of 108 older preschool children participated in the study, including 59 children who live in urban areas (32 boys and 27 girls) and 49 ones who live in rural areas (23 boys and 26 girls).

\section{Results and Discussion}

Theoretical analysis of psychological and pedagogical literature, current educational programs for preschool children development in particular «A Child», «A Sure Start», «The Ukrainian Preschooling», «The World of Childhood», «A Preschooler» allowed us to determine the criteria, indicators, and levels of older preschool children's acquaintance with the professions. Thus, we have identified the following criteria: cognitive-knowledge, motivational-value, and activity-behavioral (ZHAMARDIY et al., 2020).

Based on the defined criteria and indicators, the levels of older preschool children's acquaintance with the professions were characterized. They are the following:

High level: Children show complete and conscious knowledge of the most common professions of modern society, aware that all objects of the world are made by a human, know the structure of the labor process, labor actions, and their sequence. They have a rich stock of lexical units in active vocabulary to denote the names of professions, tools, actions performed by employees, use them in the process of game interaction. Children understand the explanations of an adult about professional activities and show the ability to explain the meaning of the names of professions and tools. They can establish a connection between the purpose and the labor result, classify professions by the type of human activity, and correlate the profession and the equipment. They show respect for people's labor and its results. They transfer knowledge and skills to different types of activities. Children independently and correctly perform the tasks of didactic games of professional orientation, clearly follow the rules of the game and do not allow violations. They show desire and motivate others to organize role-playing based on the industrial plots, create a role-playing game following their idea, knowledge, and interests, during which they use substitute subjects, role speech, and consistent game actions. They build constructions with building materials following their plan and use them in role-playing with the industrial plots (ZHAMARDIY et al., 2020). 
Sufficient level: Older preschoolers know the names of professions of their parents and people around them but are confused in the classification of professions by type of human activity. They have a sufficient stock of lexical units in active vocabulary to denote the names of professions, tools, actions performed by employees in the process of work, but they do not often use them in the process of game interaction. Children understand the explanations of an adult about professional activities and show the ability to explain the meaning of the names of professions and tools. They do not always establish the correct connection between the goal and the result of work. They know the working equipment. They show respect for people's work and the results of their work. They partially transfer the acquired knowledge and skills to various activities. The didactic game tasks are performed with the help of an adult. They express a desire to participate in joint role-playing with the industrial plots. Children create a game under the influence of emotions, interest in a certain profession with the help of an educator, during which they use attributes to the chosen profession, consistent game actions, follow game rules and notice violations. They build constructions according to the sample and use them in other games (ZHAMARDIY et al., 2020).

Low level: Older preschoolers understand but cannot explain the meaning of the most common professions and tools, rarely use their names in the process of game interaction. Children have a superficial knowledge about the professions of people close to them. They are confused in the classification of the profession by the type of activity. They have little knowledge about working equipment. They make mistakes in correlating them with the profession. In most cases, children take part in joint games; the tasks of the didactic game are performed with the help of an educator. The idea of the role game is determined by the interest in the toy and object actions. During the game children do not use attributes, perform monotonous, repetitive game actions with objects. They build in accordance with the model of the educator (ZHAMARDIY et al., 2019).

Solving the objectives of pilot research, we revealed the level of children's acquaintance with professions according to all criteria. Thus, according to the first criterion, we conducted a conversation about adult professions and played didactic games «Who works where?», «Who needs what stuff for work?».

During the survey we wanted to find out the children's opinion on the definition of term «profession»: $32.4 \%$ of children associated it with activity («it is work»), $28.7 \%$ of children associated it with a person («when adults work»), 10,2\% of children associated it with a place («where a person works»), $9.3 \%$ of children associated it with money («you are paid for it»), $19.4 \%$ of children could not answer. During the conversation, we wanted to find 
out what kind of professions children knew, as well as, whether the place of their residence affected the depth of their knowledge. We investigated that the most common professions mentioned by older preschoolers, both from urban and rural areas, were: a doctor $(68.8 \%)$, a firefighter $(36.1 \%)$, a policeman $(35.2 \%)$, a salesman $(32.4 \%)$, a builder $(31.5 \%)$, an educator $(31.5 \%)$, a cook $(31.5 \%)$, a teacher $(25 \%)$, a hairdresser $(21.3 \%)$, and a driver $(17.6 \%)$.

Analysis of the children's responses from urban and rural areas made it possible to determine a lack of children's acquaintance with:

- Sports professions: a football player (1.8\%), a coach $(2.7 \%)$, a gymnast $(0.9 \%)$;

- Medical professions: a dentist (5.5\%), a veterinarian $(2.7 \%)$, a nurse $(3.7 \%)$, a pharmacist $(1.8 \%)$

- Artistic professions: a choreographer (2.7\%), a ballerina (4.6\%), an artist (5.5\%), a musician $(1.8 \%)$, a dancer $(2.7 \%)$, a singer $(1.8 \%)$, an actor $(0.9 \%)$, a photographer $(0.9 \%)$, a presenter $(0.9 \%)$;

- Military professions: a military man $(2.7 \%)$, a pilot $(0.9 \%)$;

- Working professions: a mechanic $(0.9 \%)$, a loader $(0.9 \%)$, a secretary $(0.9 \%)$, a seamstress $(1.8 \%)$, an electrician $(0.9 \%)$, a locksmith $(0.9 \%)$.

We found that a large number of professions, whose representatives children often met in real life (an assistant educator (4.6\%), a security guard $(0.9 \%)$, a cleaner $(1.8 \%)$, a nurse (3.7\%), a headmaster $(2.7 \%)$, a janitor $(0.9 \%)$, a speech therapist $(0.9 \%)$, a baker $(0.9 \%)$, a headmaster, a music director, a conductor), they did not name during the question «What kind of professions do you know?». Analyzing the answers, we noticed that the professions that were well-known to children in the $20^{\text {th }}$ century, modern children almost do not use (an astronaut $(1.8 \%)$, a postman $(3.7 \%))$.

The answers comparison made it possible to determine that older preschool children who lived in rural and urban areas named the most common and well-known professions in modern society. But it should be noted that during the conversations with children, we noticed some differences in their answers. Children from urban areas also named professions that had become known or emerged in recent years (a cosmetologist $(1.8 \%$ ), a blogger $(1.8 \%$ ), a confectioner $(1.8 \%)$, a manager $(0.9 \%)$, a cameraman $(0,9 \%)$, a photographer $(0.9 \%)$, a cashier $(2.7 \%)$, a president $(1.8 \%)$, a taxi driver $(4.6 \%))$. We found that children did not name any of the agricultural professions in contrast to children from rural areas, who mentioned such professions as a tractor driver (4.6\%), a farmer $(1.8 \%)$, and a combine harvester $(1.8 \%)$.

RPGE- Revista on line de Política e Gestão Educacional, Araraquara, v. 25, n. esp. 3, p. 1860-1873, Sep. 2021. e-ISSN: 1519-9029 DOI: https://doi.org/10.22633/rpge.v25iesp.3.15597 
We investigated that the majority of older preschool children $(77.7 \%)$ were aware of the peculiarities of the professional activities of their family members. However, only $43.5 \%$ of respondents knew how the profession was called, $17.5 \%$ of children gave partial answers to questions, and only $6.4 \%$ of children did not know what professional activity their relatives perform.

To the question «Who works in the kindergarten?» all children answered that an educator did, and also indicated such professions as an assistant educator (48.1\%), a cook $(46.2 \%)$, a nurse $(20.3 \%)$, a headmaster $(11.1 \%)$, a doctor $(10,1 \%)$, a manager $(7.4 \%)$, a cleaner (3.7\%), a janitor (3.7\%), a music director (2.7\%), a laundryman $(2.7 \%)$.

Answering the question «Who works in the hospital?» preschoolers named such professions as a doctor (all children), a nurse (33.3\%), a cleaner (7.4\%), a dentist (5.5\%), a cook $(2.7 \%)$, a paramedic $(1.8 \%)$, an ambulance driver $(1.8 \%)$, a surgeon $(1.8 \%)$, an ophthalmologist $(1.8 \%)$, a masseur $(0.9 \%)$.

To the question «What courageous or heroic professions do you know?» most children noted that these were very complex professions, the representatives of which saved and protected people's lives. Among the courageous and heroic professions, preschoolers included the following: a firefighter (44.4\%), a police officer $(31.4 \%)$, a rescuer $(12 \%)$, a military man $(5.5 \%)$, a builder $(2.7 \%)$, a doctor $(1,8 \%)$, an ambulance worker $(1.8 \%)$, an astronaut $(1.8 \%)$, an athlete $(1.8 \%)$, a football player $(0.9 \%)$, a detective $(0.9 \%)$, a security guard $(0,9 \%)$, and $20.3 \%$ of the surveyed children did not answer.

All children answered about the peculiarities of the work performed by the builder «they build (houses, kindergartens, shops)». It should be noted that answering the question «Who else can build?» most preschoolers could not answer. Only some of them named the following building professions: a driver (7.4\%), a crane operator $(4.6 \%)$, a painter $(4.6 \%)$, and a loader $(1.8 \%)$.

All the children talked about the peculiarities of the cook's labor - «they cook food». Some preschoolers described this professional activity as follows: «a cook cooks, fries food and cuts vegetables in the kitchen», «a cook cooks cutlets, cheesecakes, soup, and washes the dishes».

The activity of the doctor was described by the majority of children $(83.33 \%)$ as follows: «treats patients». But a small number of children $(16.67 \%)$ described their work in more details, for example: «the doctor gives injections, measures the temperature, gives medication, various drops, and pills», «the doctor examines people, prescribes treatment». 
Also, during the survey, we tried to determine whether children were familiar with modern professions. The professions closest to the understanding of preschool children were chosen - an animator and a pizza maker. Analyzing the answers, we found that children from urban areas were more familiar with modern professions. The peculiarities of an animator's work were knew to $61 \%$ of preschoolers and a pizza maker $-54.2 \%$. Children from rural areas found it difficult to answer that question. $14.2 \%$ of children described the peculiarities of the animator's job, and $34.6 \%$ of children described the pizza maker's job.

The children named various heroic, courageous, and medical professions as the most important ones. Arguing for the choice of a certain profession, older preschool children gave clear comments: a doctor $(28.7 \%)$ «helps people recover», «treats people»; a police officer $(20.3 \%)$ «detains criminals», «protects everyone»; a firefighter $(11.1 \%)$ «saves people from fire»; a cook (4.6\%) «cooks delicious food», «feeds all people so that they can work»; a builder (4.6\%) «everyone needs housing»; a driver $(3.7 \%)$ «takes you where you need»; a rescuer $(2.7 \%)$ «helps people»; an educator $(2.7 \%)$ «teaches children»; a president $(2.7 \%)$ «is the main one»; a dentist $(1.8 \%)$ «treats toothache»; an ambulance worker $(1.8 \%)$ «saves people and treats diseases»; a military man $(1.8 \%)$ «protects people from war»; a detective $(0.9 \%)$ «can get to know about everything»; a veterinarian $(0.9 \%)$ «saves animals»; a tractor driver $(0.9 \%)$ «wheat will not grow without them, there will be no bread».

One of the objectives of our survey was to determine whether gender and place of birth affected children's preferences for choosing a particular profession. To do this, we asked the children to think, "Whom would you like to be when you grow up?». Analysis of children's responses made it possible to find out that the most desirable professions for boys from urban $(\mathrm{U})$ and rural $(\mathrm{R})$ areas were the following ones: a police officer $(\mathrm{U}-25 \%),(\mathrm{R}-$ $34.7 \%)$; a firefighter $(\mathrm{U}-9.3 \%),(\mathrm{R}-13 \%)$; a driver $(\mathrm{U}-6.2 \%),(\mathrm{R}-17.3 \%)$; a machinist ( $\mathrm{U}-6.2 \%),(\mathrm{R}-8.6 \%)$. Justifying their choice, they gave the following explanations: «I want to be a policeman because my father is a policeman», «I want to protect my mother», «I like the police uniform», «I will protect people», «I will drive a police car»; «I will save people», «I dream of riding a fire truck»; «I love cars», «I want to be like my dad», «I will give people a lift», «I will drive KAMAZ»; «I will transport people», «I like to go by train».

The boys also named the following professions: a military man, a racer, a builder, a pilot, a mechanic, an athlete, a superhero, a detective. Among the professions, the boys from urban areas also chose the following: a taxi driver, a cashier, a president, a dentist, an archaeologist, a programmer, a lifeguard, a boss, a trainer, a hairdresser, a confectioner. The 
boys from rural areas, in contrast to urban ones, chose professions related to technology and agriculture.

Analyzing the answers of girls from urban (U) and rural (R) areas, we found that most often they named the following professions: a doctor ( $\mathrm{U}-18.5 \%),(\mathrm{R}-19.2 \%)$; a hairdresser $(\mathrm{U}-18.5 \%),(\mathrm{R}-15.3 \%)$; a cook $(\mathrm{U}-7.4 \%),(\mathrm{R}-11.5 \%)$; a veterinarian $(\mathrm{U}-$ $11.1 \%),(\mathrm{R}-7.6 \%)$. Arguing their choice, they made the following comments: «I dream that people do not get sick», «I like to treat dolls», «I want to be like my mother»; «I can do hairstyles», «I would like to work in a beauty salon», «I like making hairstyles for dolls»; «I like helping my mother in the kitchen», «I will work in a cafe»; «I love animals», «I want to treat animals».

The girls also preferred artistic professions: for example, a ballerina, a model, a singer, a gymnast, a dancer, a choreographer, an artist, a presenter. The following professions were also named: a dentist, a nurse, a teacher, a sales assistant, an educator, an actress, a flight attendant. Only a few girls chose professions that were more specific to men: a police officer ( $U-7.6 \%)$, military $(R-3.8 \%)$, and a firefighter $(U-3.7 \%)$. The children explained their choice as follows: «My mother works there», «I like clothes»; «I dream of becoming a general, I will command everyone and my father will not go to war"; "I want to save people and cats».

Analysis of children's responses allowed us to state the lack of older preschool children's acquaintance with the professions of adults. Preschoolers knew the most common professions (a policeman, a doctor, a firefighter, a driver, a teacher, a hairdresser, an educator, a salesman), but sports, art, working, military, medical professions were out of their attention. Children were well acquainted with their relatives' professional duties, but many of them did not know how these professions were called. Describing the work of a doctor, a builder, a cook, children mostly gave a brief, general description without going into details. The most important professions for the vast majority of children were heroic, courageous professions, which were associated with people's protection and rescue.

The game «Who works where?» result showed that older preschool children were mostly acquainted with the workplaces of representatives of various professions $(51 \%)$. Preschoolers made mistakes in matching such professions with the workplace as a seamstress, a builder, a teacher, an educator, an astronaut. During the game «Who needs what stuff for work» children found it difficult to match pairs between the employee and the tools $(60 \%)$, children showed knowledge of the professions - a hairdresser, an artist, a cook, and made 
mistakes in matching working professions. During the game, participants needed some help from an adult, but a significant number of children followed the rules of the game.

To determine children's acquaintance according to the second and third criteria, we monitored the older preschoolers' play activities. The observation made it possible to determine the presence of motives that stimulated children to help adults, identify a conscious attitude to the work of others and the availability of theoretical knowledge and skills to use them in practice, and the desire to work.

Children were offered to role-play («A kindergarten", «A hospital», «A shop») and building («On the farm», «A shop», «A stadium») games. Observations showed that most children were willing to participate in play activities. They could select and use attributes of well-known professions. We observed that preschoolers in the process of role-playing transferred their life experience, which they gained observing or communicating with adults to transform into the chosen profession (spoke in tone and the intonation of their educator, the doctor or the shop assistant they knew, used their phrases, imitated their movements and behavior). However, we found that most of the games were offered by the educator, and children themselves rarely showed an independent desire to make a game. The children had problems with the distribution of roles because they mostly preferred such professions as an educator, a doctor, a cashier, which led to conflict situations.

\section{Conclusions}

Thus, the study shows that older preschool children have superficial knowledge about the professional activities of adults. Of the total number of preschoolers who has participated in the study (108 children), only $15.7 \%$ of children show a high level of acquaintance with professions, $48.2 \%$ of children show a sufficient one, and $36.1 \%$ of children show a low one. The vast majority of children understands the names of adult professions but cannot explain the peculiarities of their professional activities. They name and describe work activities. Preschoolers name tools, but rarely use their names in the process of game interaction. In their active speech, children are more likely to use words related to the most common professions. Preschoolers show insufficient acquaintance with sports, art, working, military, and medical professions. We have found out the influence of gender and place of residence on the older preschool children's acquaintance with professions. When analyzing children's answers, we have found that girls are more likely to turn to professions related to caring, service, and boys prefer heroic, courageous, hard-working professions that relate to helping people, leadership, 
and technology. We have revealed that children from urban areas know more representatives of different professions, and are more familiar with modern professions, and pay less attention to gender stereotypes in choosing a profession.

Further development requires deepening children's understanding of all professions, acquaintance with their specifics, clarification of knowledge about objects and equipment, and the development of the ability to use their knowledge in practice. The obtained data testify to the high relevance and importance of acquainting preschool children with the labor of adults in the process of professional development of personality.

\section{REFERENCES}

ANTONOVA, M. V.; GRISHNJAEVA, I. V. Early career guidance as an element of sociocommunicative and cognitive development of preschool children. Modern high technology, 2, 93-96, 2017.

CHIHIRINA, O. V. Forms of vocational guidance work in the conditions of PEI. Preschool educational institution, 3,3-30, 2011.

CONEWAY, B.; HWANG, S., GOODRICH, J.; KIM, L.; EGBERT, E. Planting the Seeds of College and Career Readiness in Preschool. Journal of Applied Research on Children.

Journal of Applied Research on Children: Informing Policy for Children at Risk. 2020. Available:

https://digitalcommons.library.tmc.edu/cgi/viewcontent.cgi?article=1411\&context=childrenat risk.

DONCHENKO, V. I.; ZHAMARDIY, V. O.; SHKOLA, O. M.; KABATSKA, O. V.; FOMENKO, V. H. Health-saving Competencies in Physical Education of Students. Wiadomości Lekarskie, Tom LXXIII, 1, 145-150, 2020.

GRIBAN, G.; PRONTENKO, K.; ZHAMARDIY, V.; TKACHENKO, P.; KRUK, M.; KOSTYUK, Y.; ZHUKOVSKYI, Y. Professional Stages of a Physical Education Teacher as Determined Using Fitness Technologies. Journal of Physical Education and Sport, 18 (2), 565-569, 2018.

GUILFOYLE, C. For college and career success, start with preschool. Policy Priorities, 19(4), 1-7, 2013.

HNIZDILOVA, O.; LUKASHOVA, YU. Preschoolers' career guidance by means of didactic games. Pedagogical sciences, 75-83, 2020.

HNIZDILOVA, O.; LUKASHOVA, YU. The use of cartoons in the early career guidance of preschoolers. Humanization of the educational process, 1(99), 214-225, 2020.

KONONETS, N.; GRYNOVA, M.; ZHAMARDIY, V.; MAMON, O.; LIULKA, H. Problems of Implementation of The System of Resource-Based Learning of Future Teachers 
of Physical Culture. International Journal of Applied Exercise Physiology, 9 (12), 50-60, 2020.

KORNOSENKO, O.; DENYSOVETS, T.; DANYSKO, O.; SYNYTSYA, S.;

VOLOSHKO, L.; ZHAMARDIY, V.; DONCHENKO, V.; SHKOLA, O.;

PRYSTYNSKYI, V.; OTRAVENKO, O. System of Preparation of Future Fitness Coaches'

for Health-Improving Activity in the Conditions of Rehabilitation Establishments.

International Journal of Applied Exercise Physiology, 9 (8), 33-41, 2020.

LOHINOVA, V. Formation of an idea of the work of adults. Preschool education, 10, 56-63, 1978.

MAKEEVA, G. The formation of ideas about the work of adults. Preschool education, $2,83-85,1989$.

SHKOLA, O.; GRIBAN, G.; PRONTENKO, K.; FOMENKO, O.; ZHAMARDIY, V.; BONDARENKO, V.; BEZPALIY, S.; ANDREYCHUK, V.; TKACHENKO, P.; BLOSHCHYNSKY, I.; ZHUKOVSKYI, Y.; NOVITSKA, I. Formation of Valuable Orientations in Youth during Physical Training. International Journal of Applied Exercise Physiology, 8(3.1), 264-272, 2019.

SHKOLA, O.; ZHAMARDIY, V.; SAIENKO, V.; TOLCHIEVA, H.; POLULIASHCHENKO, I. The Structure Model of Methodical System Usage FitnessTechnology in Student Physical Education. International Journal of Applied Exercise Physiology, 9 (10), 89-96, 2020.

YERSHOVA, I. V. Organization of early vocational guidance for preschoolers. Field of knowledge, 1, 32-33, 2013.

ZHAMARDIY, V. O.; DONCHENKO, V. I.; YEMETS, A. V.; SKRINNIK, Y. O. Physical Development by Means of Fitness Technologies as One of General Aspects of Student's Health. Wiadomości Lekarskie. Tom LXXII, nr 5 cz II, 1074-1078; 2019.

ZHAMARDIY, V.; GRIBAN, G.; SHKOLA, O.; FOMENKO, O.; KHRYSTENKO, D.; DIKHTIARENKO, Z.; YEROMENKO, E.; LYTVYNENKO, A.; TERENTIEVA, N.; OTRAVENKO, O.; SAMOKISH, I.; HUSAREVYCH, O.; BLOSHCHYNSKYI, I. Methodical System of Using Fitness Technologies in Physical Education of Students. International Journal of Applied Exercise Physiology, 9 (5), 27-34, 2020.

ZHAMARDIY, V.; SHKOLA, O.; BEZPALIY, S.; KALYNOVSKYI, B.; VASYLENKO, O.; IVANOCHKO, I.; DOVGAN, N.; MALYNSKYI, I.; DANYLENKO, O.; GRIBAN, G.; PRONTENKO, K. Modern Fitness Technologies in the Physical Education of Students. Revista Dilemas Contemporáneos: Educación, Política y Valores. Año: VII, Número: Edición Especial, Artículo no.: 81. Período : Noviembre, 2019.

ZHAMARDIY, V.; SHKOLA, O.; BOICHENKO, A.; PRYSTYNSKYI, V.; KORNOSENKO, O.; DMYTRENKO, K.; KABATSKA, O.; STAROSELSKA, Y.; HORDIIENKO, O.; POSTOVA, S. Dynamics of Physical Fitness of Students during Powerlifting Classes. International Journal of Applied Exercise Physiology, 9 (9), 49-60, 2020. 
ZHAMARDIY, V. O.; SHKOLA, O. M.; OKHRIMENKO, I. M.; STRELCHENKO, O. G.; ALOSHYNA, A. I.; OPANASIUK, F. H.; GRIBAN, G. P.; YAHODZINSKYI, V. P.; MOZOLEV, O. M.; PRONTENKO, K. V. Checking of the Methodical System Efficiency of Fitness Technologies Application in Students' Physical Education. Wiadomości Lekarskie, Tom LXXIII, nr 2, 332-341, 2020.

ZHAMARDIY, V.; SHKOLA, O.; OTRAVENKO, O.; MOMOT, O.; ANDREIEVA, M.; ANDRIEIEVA, O.; MUDRYK, V.; SLUSAREV, V.; BROSLAVSKA, H.; PUTIATINA, G. Dynamics of the Functional State of Students in the Process of Powerlifting in Higher Education. International Journal of Applied Exercise Physiology, 9(10), 24-35, 2020.

ZHAMARDIY, V.; SHKOLA, O.; SAIENKO, V.; TOLCHIEVA, H. Model of Pedagogical System for Teaching Students Motor Actions in Powerlifting. International Journal of Applied Exercise Physiology, 9(12), 76-85, 2020.

ZHAMARDIY, V.; SHKOLA, O.; TOLCHIEVA, H.; SAIENKO, V. Fitness Technologies in the System of Physical Qualities Development by Young Students. Journal of Physical Education and Sport, 20 (1), 142-149, 2020.

ZHAMARDIY, V.; SHKOLA, O.; ULIANOVA, V.; BILOSTOTSKA, O.; OKHRIMENKO, I.; OKHRIMENKO, S.; GRIBAN, G.; PRONTENKO, K.; BLOSHCHYNSKYI, I. Influence of Fitness Technologies on the Student Youth's Physical Qualities Development. Revista Dilemas Contemporáneos: Educación, Política y Valores. Año: VII, Número: Edición Especial, Artículo no.: 49. Período : Octubre, 2019.

\section{How to reference this article}

HNIZDILOVA, O.; LUKASHOVA, Y.; BURSOVA, S.; YUDINA, N.; HRYSHKO, O. Experimental study of the older preschool children's vocabulary development while acquainting with professions. Revista on line de Política e Gestão Educacional, Araraquara, v. 25, n. esp. 3, p. 1860-1873, Sep. 2021. e-ISSN: 1519-9029. DOI: https://doi.org/10.22633/rpge.v25iesp.3.15597

Submitted: $20 / 03 / 2021$

Required revisions: 05/06/2021

Approved: $12 / 07 / 2021$

Published: 01/08/2021 